\title{
Pelatihan Komputer Akutansi Desa dengan Aplikasi Keuangan Desa (Siskuedes) untuk Meningkatkan Profesionalitas Guru
}

\author{
Cipto Wardoyo*1, Slamet Fauzan², Rizky Firmansyah ${ }^{3}$, Noor Faresi Putra ${ }^{4}$ \\ 1,2Program Studi Pendidikan Akuntansi, Fakultas Ekonomi, Universitas Negeri Malang, Indonesia \\ 3,4 Program Studi Akuntansi, Fakultas Ekonomi, Universitas Negeri Malang, Indonesia \\ *e-mail: cipto.wardoyo.fe@um.ac.id ${ }^{1}$, slamet.fauzan.fe@um.ac.id², rizky.firmansyah.fe@um.ac.id ${ }^{3}$, \\ noor.faresi.1904226@students.um.ac.id 4
}

\begin{abstract}
Abstrak
Penerbitan Undang-Undang Nomor 6 tentang Desa Tahun 2014 dan Peraturan Menteri Nomor 113 Tentang Pengelolaan Keuangan Desa telah menarik perhatian publik. Mengingat dana langsung pemerintah ke desa mencapai $10 \%$ dari total anggaran pendapatan dan belanja negara, tentu diperlukan sistem akuntabilitas yang jelas. Adanya aplikasi SISKEUDES yang dibangun oleh BPKP bersama Kementrian Dalam Negeri yang didistribusikan ke desa-desa di seluruh Indonesia secara gratis melalui pemerintah kabupaten/kota, diharapkan mampu mempermudah pengelolaan keuangan desa dengan tujuan sebagai upaya mengawal transparansi pengelolaan dana desa. Hal ini menarik perhatian dunia pendidikan, khususnya SMK yang memasukkan materi pembelajaran akuntansi desa berbasis IT pada tahun ajaran 2019/2020 sesuai Kurikulum 2013. Kegiatan pengabdian ini bermaksud untuk menjembatani demi meningkatkan pemantapan wawasam dan profesionalitas guru akuntansi SMK se-Kota Malang terhadap sistem keuangan desa serta pengoprasian sistem aplikasi siskeudes. Metode yang digunakan dalam kegiatan ini yaitu pelatihan dan pengajaran aplikasi sistem keuangan desa. Hasil pengabdian ini adalah guru akuntansi di MGMP Akuntansi Kota Malang menjadi lebih meningkat kompetensi profesionalnya dalam mengajar komputer akuntansi desa. Hal ini dilihat dari antusias peserta dalam menyelesaikan modul komputer akuntansi desa. Selain itu juga dapat dilihat dari meningkatnya nilai rata-rata peserta dari nilai pre test sebesar 5,5 menjadi rata-rata 6,7. Selepas adanya kegiatan pengabdian ini diharapkan apa yang telah diajarkan pendidik berhasil dipahami dengan lancar oleh peserta didik yang outputnya dapat melahirkan lulusan peserta didik yang kompeten dalam mengambil peran penting yakni menjadi operator dalam mengoprasikan aplikasi siskeudes.
\end{abstract}

Kata kunci: Akuntansi Desa, Aplikasi Siskuedes, Profesionalitas Guru

\begin{abstract}
The issuance of Law Number 6 concerning Villages of 2014 and Ministerial Regulation Number 113 concerning Village Financial Management has attracted public attention. Given that direct government funds to villages reach $10 \%$ of the total state budget for revenues and expenditures, a clear accountability system is needed. The existence of the SISKEUDES application, which was built by BPKP together with the Ministry of Home Affairs, which is distributed to villages throughout Indonesia for free through district/city governments, is expected to facilitate village financial management with the aim of overseeing the transparency of village fund management. This has attracted the attention of the education world, especially SMKs that include IT-based village accounting learning materials in the 2019/2020 academic year according to the 2013 Curriculum. This service activity intends to bridge the gap in order to improve the insight and professionalism of SMK accounting teachers in Malang City towards the village financial system and the operation of the siskeudes application system. The method used in this activity is training and teaching the application of the village financial system. The result of this service is that accounting teachers at the Malang City Accounting MGMP have further increased their professional competence in teaching village accounting computers. This can be seen from the enthusiasm of the participants in completing the village accounting computer module. In addition, it can also be seen from the increase in the average score of participants from the pre-test score of 5.5 to an average of 6.7. After this service activity, it is hoped that what has been taught by educators can be successfully understood by students whose outputs can give birth to graduates of students who are competent in taking an important role, namely being an operator in operating the siskeudes application.
\end{abstract}

Keywords: Village Accounting, Siskuedes Application, Teacher Professionalism 


\section{PENDAHULUAN}

Kegiatan pengabdian ini didasarkan pada implikasi ditetapkannya Undang-Undang Desa No. 6 Tahun 2014 yang menyebabkan pemerintah desa diberikan kewenangan untuk mengelola pendapatan dan dana bagi kesejahteraan desa. Dana diberikan untuk kesejahteraan desa yang erat kaitannya dengan pemerataan pembangunan desa yang dipusatkan berdasarkan dana APBN (Anggaran pengeluaran \& Belanja Negara) yang jumlahnya mencapai milyaran rupiah [1]. Udang-Undang Desa ini berisakan tentang kewenangan yang diberkan kepada desa dibidang aplikasi pembangunan, pembinaan kemasyarakatan, pemberdayaan masyarakat serta penyelenggaraan pemerintahan desa berdasarkan prakarsa masyarakat [2].

Besarnya dana yang diberikan pemerintah kepada desa tentunya akan berdampak pada proses pengelolaan yang harus dilakukan secara efektif, profesional, dan bertanggung jawab [3]. Oleh karena itu, diperlukan suatu pengelolaan keuangan desa yang meliputi pelaksanaan, perencanaan, pengelolaan serta laporan yang akuntabel yang baik dan memadai [4]. Selain itu, perlunya pengawasan keuangan desa yang lebih ketat sekaligus sumber daya manusia yang kompeten untuk mengelola dana tersebut [5].

Menanggapi hal tersebut pemerintah memberikan sebuah aplikasi bernama SISKEUDES yang dapat membantu pemerintah desa dalam mengoperasikan keuangan desa. Aplikasi SISKEUDES diharapakan dapat mempermudah aparatur pemerintah desa dalam mengelola sistem keuangan desa dari tahap perencanaan awal hingga tahap pelaporan pertanggungjawaban [6]. Sedangkan untuk menanggapi kebutuhan sumberdaya manusia yang kompeten upaya yang dilakukan oleh wakil mentri keuangan RI, Prof. Mardiasmo, adalah dengan meminta Lembaga Pendidikan menyiapkan lulusan yang memahami akuntansi pemerintahan [7].

Sekolah Menegah Kejuruan (SMK) adalah salah satu sekolah terobosan untuk mempersiapkan tenaga terampil sesuai di masing-masing bidang keahliannya sebagai upaya pemerintah ke depan untuk menumbuhkan sumber daya manusia yang unggul [8]. Persiapan tersebut selaras dengan kurikulum 2013 yang baru, terdapat adanya mata pelajaran baru yang baru saja diimplementasikan dan masih belum diajarkan sebelumnya yaitu tentang akuntansi desa [9]. Diajarkannya mata pelajaran ini berkenaan dengan adanya Undang-Undang Nomor 6 tentang Desa Tahun 2014 dan Peraturan Mentri 113 tentang pengelolaan keuangan desa Tahun 2014. Oleh sebab itu, sebagian besar guru SMK masih belum menguasi sepenuhnya mata pelajaran baru ini dari segi pemaparan materi maupun praktiknya [10].

Guru Akuntansi pada umumnya tidak mengenal sistem keuangan desa dengan aplikasi siskeudes [11]. Apalagi sistem keuangan desa termasuk dalam mata pelajaran baru di kurikulum 2013 sehingga guru SMK khususnya guru akuntansi tidak siap dalam memberikan bahan ajar baik materi dan pengoperasian aplikasi SISKEUDES ke siswanya [8]. Oleh karena itu, Sekolah Menenga Kejuruan (SMK) mengalami kendala dalam SDM yang berkompeten dalam sistem keuangan desa dan pengoperasian aplikasi SISKEUDES sehingga tujuan pembelajaran belum tercapai secara optimal [12]. Jika hal ini tidak segera dicari solusinya, maka guru tidak akan memiliki performance di depan siswa dalam mengajar komputer akuntansi desa. Selain itu, siswa juga akan merasa kesulitan menerima materi dari guru tersebut.

Berdasar uraian di atas, maka perlu dilakukan pembinaan-pembinaan kepada guru SMK tentang mata pelajaran sistem keuangan desa serta penerapan dan pengoperasian aplikasi Sistem Keuangan Desa supaya lebih siap dalam mengampu materi tersebut kepada siswanya. Oleh karena itu dengan diadakannya kegiatan pengabdian ini diharapkan dapat meningkatkan pengetahuan pengajar akuntansi di Sekolah Menengah Kejuruan terhadap sistem keuangan desa meliputi perencanaan, penganggaran, penatausahaan dan pelaporan keuangan desa. Pemerintah desa merencanakan dalam rangka pembangunan desa sesuai wewenangannya [11]. Implementasi adalah tahap dimana rencana yang sudah ada direalisasikan dan dilaksanakan secara bertahap. Penganggaran adalah proses memasukkan data tentang kegiatan yang dilakukan selama tahun berjalan. Pengelolaan tersebut dicatat dalam buku tabungan bank, dan rekening pembantu pajak. Pelaporan adalah proses penyusunan anggaran dan realisasi anggaran pendapatan dan belanja desa [12]. Setelah adanya kegiatan pengabdian tersebut 
diharapkan siswa dapat dengan mudah memahami konten yang disampaikan oleh pendidik yang outputnya mampu melahirkan lulusan siswa yang kompeten dan siap untuk mengambil peran yang sangat penting yaitu menjadi operator mengoperasikan aplikasi SISKEUDES.

\section{METODE}

Metode kegiatan ini pada dasarnya adalah pelatihan dan pengajaran. Kegiatan awal adalah pengenalan awal tentang sistem keuangan tingkat desa, yang bertujuan agar peserta memberikan pemahaman tentang perangkat lunak yang disediakan sebelum mereka dapat mempraktekkannya. Selain itu, instruktur menginstal software di masing-masing laptop dan mempraktekan aplikasinya langsung di masing-masing laptop. Metode bimbingan dirancang untuk memberikan motivasi dan pengawasan kepada para pelaku kegiatan. Dengan bantuan ini, guru diharapkan dapat memahami sepenuhnya penerapan sistem keuangan pedesaan dan mengajarkannya kapada siswanya.

Partisipan dalam pengabdian ini adalah guru akuntansi MGMP Kota Malang. Alat yang digunakan adalah komputer yang sudah terinstal aplikasi siskeudes. Bahan yang digunakan adalah modul akuntansi keuangan desa. Untuk persiapan, tim pengabdian melakukan langkahlangkah:

1. Pre test dengan materi sistem keuangan desa

2. Mempelajari kompetensi yang diharapkan dari mapel akuntansi desa di tingkat SMK melalui aktivitas diskusi dengan guru mapel akuntansi pemerintahan

3. Mengumpulkan serangkaian referensi yang relevan, yaitu referensi tentang sistem keuangan desa

4. Merancang format buku-buku yang diperlukan bagi penatausahaan keuangan desa

5. Merancang ragam transaksi yang relevan

6. Merancang format laporan keuangan desa

7. Melaksanakan kegiatan pengabdian untuk menjelaskan dan mempraktekkan penatausahaan keuangan desa, dan menyiapkan laporan keuangan desa, termasuk laporan APBDes dan laporan kekayaan desa

8. Post test dengan materi sistem keuangan desa

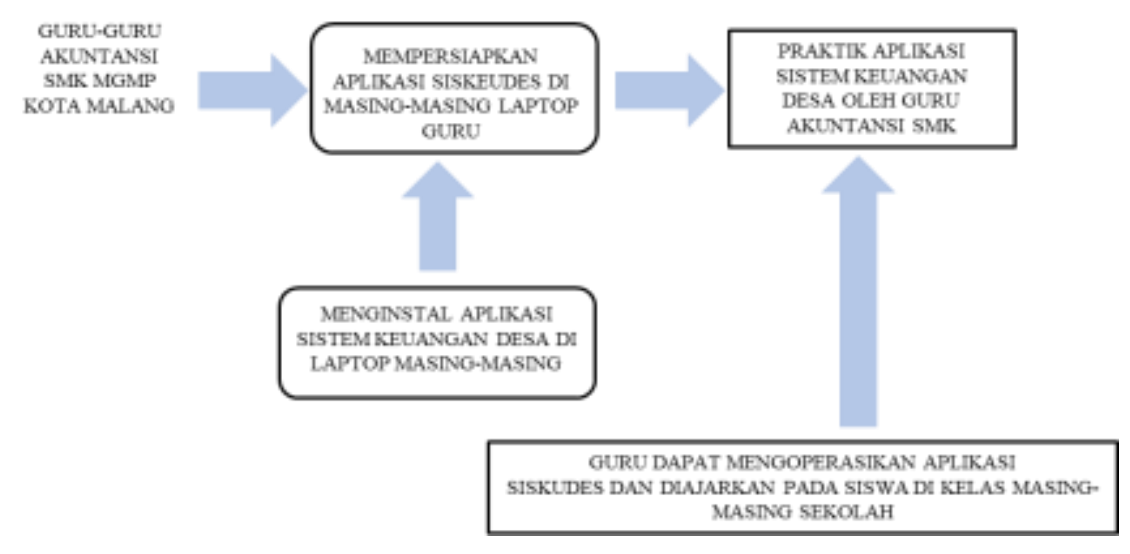

\section{Gambar 1. Rancangan Pengabdian MGMP Guru Akuntansi SMK se-Kota Malang}

\section{HASIL DAN PEMBAHASAN}

Peserta pelatihan dan pendampingan sistem keuangan desa dan praktik pengoperasian aplikasi SISKEUDES ini adalah MGMP Guru Akuntansi SMK se-Kota Malang. Sebelum terselengaranya kegiatan pelatihan ini, tim pengabdian melakukan koordinasi dengan guru SMK 
se-Kota Malang untuk merealisasikan kegiatan pelatihan. Kegiatan ini dilaksanakan pada tanggal 3 Juli 2021 di hotel Atria Malang.

Kegiatan pelatihan ini dimulai dengan pemaparan materi sistem keuangan yang dipresentasikan dari tim pengabdian ini diantaranya perencanaan, penganggaran, penatausahaan dan pelaporan keuangan desa.
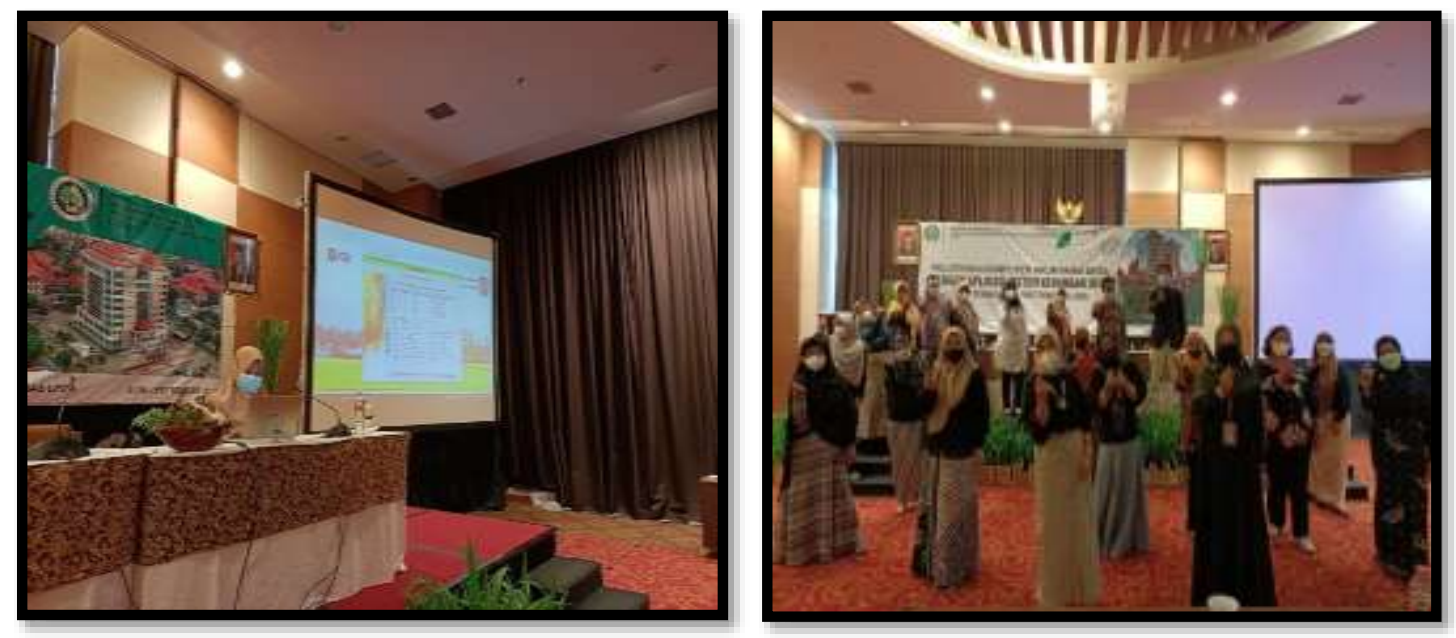

Gambar 2. Pemaparan Materi Sistem Keuangan Desa dan Foto bersama peserta

Kemudian dilanjutkan dengan pelatihan pengoperasian aplikasi SISKEUDES yang telah disiapkan di laptop masing-masing peserta yang sebelumnya telah diinstal sebelum kegiatan berlangsung. Pada sesi ini, peserta diberikan deskripsi terkait menu data entri utama SISKEUDES meliputi 5 modul, yaitu:

1. Perencanaan, berfungsi sebagai informasi rencana desa yang meliputi visi, misi, dan RP JM desa.

2. Penganggaran, berfungsi sebagai penyusunan anggaran dengan output utama APBDes \& Kas,

3. Penatausahaan, berfungsi sebagai pelaksanaan APBDes yang telah disusun, meliputi pengajuan SPP, pencairan dan pertanggungjawaban dengan output buku penatausahaan keuangan desa,

4. Pembukuan, berfungsi sebagai penyusunan laporan keuangan desa

5. Laporan, berisi informasi terkait laporan pelaksanaan anggaran APBDes, RAB, dan laporan kekayaan milik desa.
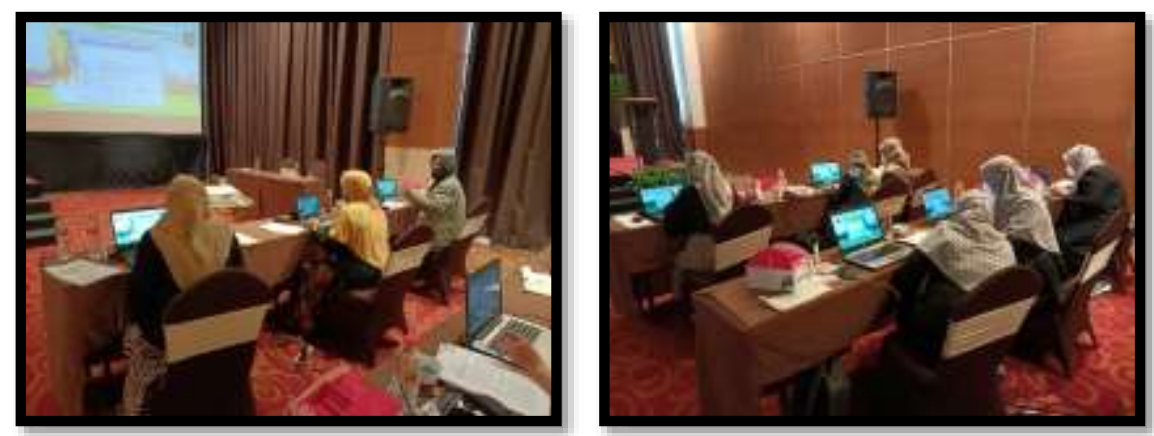

Gambar 3. Pengoperasian Aplikasi Siskeudes

Setelah itu, untuk mengoptimalkan pemahaman guru SMK terkait praktik dalam pengoperasian aplikasi SISKEUDES, tim pengabdian memberikan modul pelatihan soal 
siskeudes yang sudah disiapkan. Disini tim pengabdian memandu dalam melakukan pengsisian data dalam aplikasi siskeudes untuk menunjang pemahaman peserta dalam menginput data di aplikasi SISKEUDES.
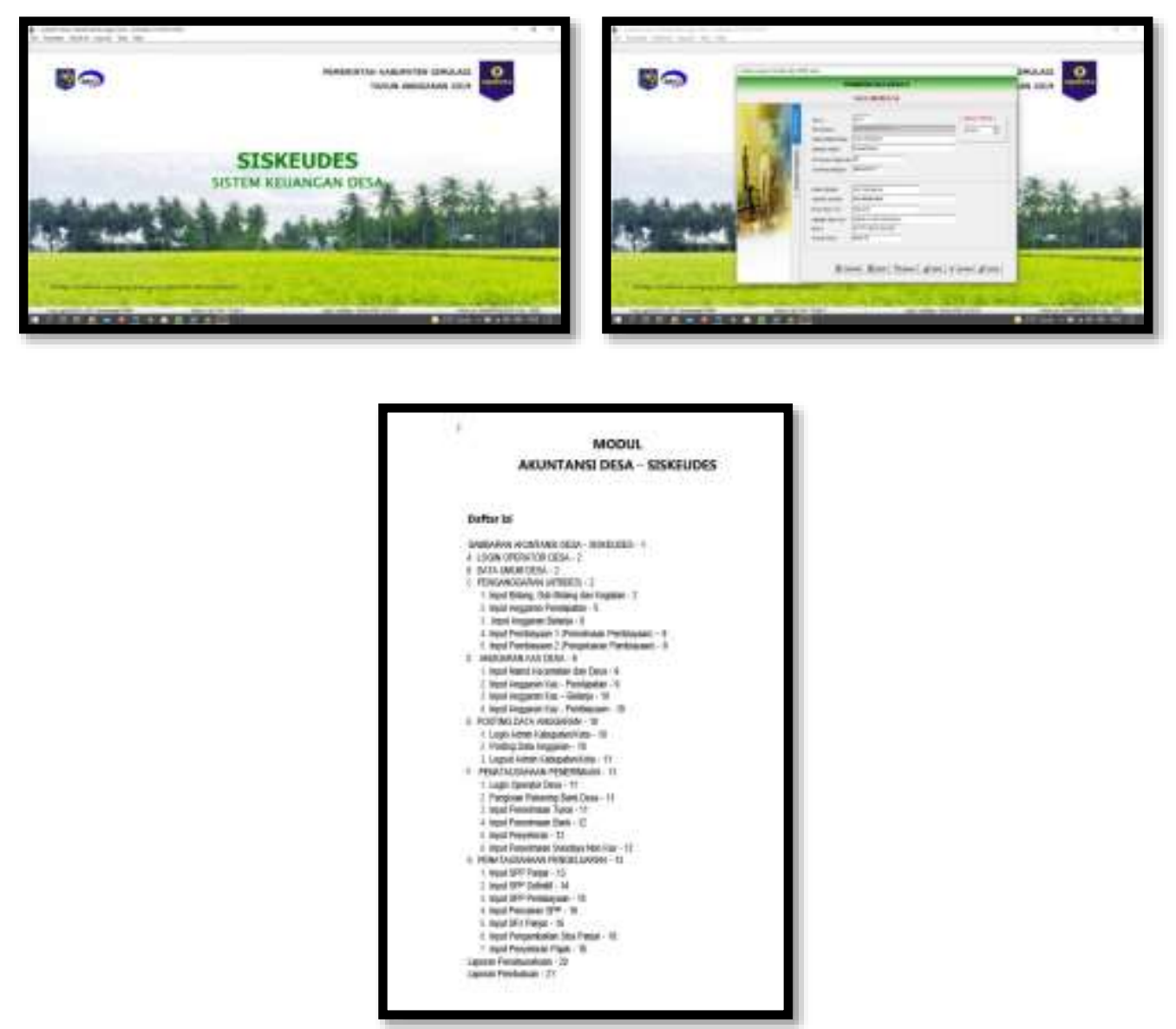

Gambar 4. Tampilan Umum Siskeudes \& Modul Pelatihan

Secara keseluruhan kegiatan pelatihan sistem keuangan desa dan pengoperasian aplikasi SISKEUDES berjalan lancar dan efektif. Hal ini dapat dilihat dari nilai post test materi sistem keuangan desa peserta sebesar 6,7. Nilai tersebut mengalai kenaikan dari nilai pre test yang memiliki nilai rata-rata 5,5. Disamping itu juga terlihat dari antusiasme peserta yang mengikuti semua acara pelatihan dari pemaparan materi sistem keuangan desa sampai denga penugasan soal siskeudes. Selama kegiatan berlangsung, peserta sangat kooperatif dengan mengikuti semua instruksi yang diberikan dan datang tepat waktu dalam kegiatan pelatihan ini. Diakhir acara para peserta mengungkapkan kebermanfaatan progam pelatihan ini mengenai pengoperasian aplikasi SISKEUDES secara penuh dan para peserta menjadi lebih siap dalam mengampu materi sistem keuangan desa dan pengoperasian aplikasi SISKEUDES kepada siswanya untuk melahirkan lulusan berkompeten di masa akan datang.

\section{KESIMPULAN}

Kegiatan pelatihan komputer akuntansi desa dengan aplikasi SIEKUDES bagi MGMP Guru Akuntansi SMK se-Kota Malang dapat terlaksana dengan lancar dilihat dari para peserta yang kooperatif dan kondusif. Hasil dari kegiatan ini para peserta mengalami kenaikan dalam mengoperasikan aplikasi SISKEUDES. Hal ini terlihat dari nilai rata-rata post test materi sistem keuangan desa naik menjadi 6,7 dari nilai pre test yang memiliki nilai rata-rata 5,5. Dengan adanya kegiatan ini menunjukan peningkatan profesionalitas guru dalam mengoperasikan aplikasi sistem keuangan desa. Guru menjadi lebih siap dalam mengajarkan materi dan praktik siskeudes ke siswanya dengan output menghasilkan lulusan kompeten. 
Dikarenakan pelatihan ini sangat terbatas yang hanya dilaksanakan selama sehari dengan materi dan praktik yang sangat padat. Diharapkan untuk kegiatan pengabdian selanjutnya pemaparan terkait materi dan praktik dilakukan secara terpisah supaya saat kegiatan praktik pengoperasian aplikasi SISKEUDES dapat berjalan dalam kondisi optimal, dikarenakan pemaparan konsep materi yang cukup panjang akan mengurangi konsentrasi peserta pada sesi praktik penggunaan aplikasi.

\section{UCAPAN TERIMA KASIH}

Tim pengabdian mengucapkan terimakasih yang sebesar-besarnya kepada Rektor Universitas Negeri Malang yang telah memberikan dana untuk kegiatan pengabdian ini dan kepada MGMP guru akuntansi SMK se-Kota Malang yang telah mengikuti kegiatan pengabdian ini.

\section{DAFTAR PUSTAKA}

[1] R. Martini, R. Agustin, A. Fairuzdita, and A. N. Murinda, "Pengelolaan Keuangan Berbasis Aplikasi Sistem Keuangan Desa," J. Pengabdi. Kpd. Masy., vol. 25, no. 2, pp. 69-74, 2019.

[2] A. Rahmawati, "Implementasi Peraturan Menteri Dalam Negeri Nomor 113 Tahun 2014 Tentang Pengelolaan Keuangan Desa," J. Ilmu Adm. Publik, vol. 9, no. 1, pp. 1-5, 2020.

[3] Endang and R. Hayati, "Implementasi Apliksai Sistem Keuangan Desa Dilihat Dari Aspek Sumber Daya Di Desa Bentot Kecamatan Patangkep Tutui Kabupaten Barito Timur," J. Adm. Publik Adm. Bisnis, vol. 3, no. 2, pp. 893-903, 2020.

[4] I. Rakhmawati, B. R. Dwi Astuti, S. Hendri BS, and W. Suhaedi, "Pelatihan Sistem Aplikasi Keuangan Desa," J. Abdimas Indep., vol. 1, no. 1, pp. 59-67, 2020, doi: 10.29303/independen.v1i1.4.

[5] N. Hasanah, A. Fauzi, and I. Mulyasari, "Peningkatan Kompetensi Guru SMK dalam Membentuk Sumber Daya Manusia Unggul di Institusi Pemerintahan," J. Pemberdaya. Masy. Madani, vol. 3, no. 2, pp. 333-347, 2019, [Online]. Available: https://doaj.org/article/7bf7a969e6bb42a889b2b60eaffd1d46.

[6] I. Muhammad, A. K. Widagdo, and A. Widodo, "Sistem Akuntansi Pengelolaan Dana Desa," Sist. Akunt., vol. 19, no. 2, pp. 323-340, 2016.

[7] R. Anggraini, N. Hasanah, A. Fauzi, and T. hesti Utaminingtyas, "Peningkatan Pemahaman Guru-Guru SMK melalui Pelatihan Akuntansi Pemerintah Guna Menyiapkan SDM Instansi Pemerintah," J. Pemberdaya. Masy. Madani, vol. 2, no. 2, pp. 338-354, 2018, [Online]. Available: https://doaj.org/article/7bf7a969e6bb42a889b2b60eaffd1d46.

[8] Gusnardi, A. Hasan, Suarman, Nasrizal, and R. Riadi, "Pelatihan Akuntansi Keuangan Lembaga Bagi Guru Smk Dalam Menyiapkan Tenaga Operator Keuangan Desa Dalam Masa Pandemi (Mgmp Akuntansi Kota Pekanbaru)," J. Pengabdi. UntukMu NegeRI, vol. 4, no. 2, pp. 211-221, 2020, doi: 10.37859/jpumri.v4i2.2117.

[9] B. Hadi, "Tantangan Penerapan Kurikulum Akuntansi Pemerintahan Untuk SMK Kelompok Keahlian Bisnis dan Manajemen dengan Adanya UU Desa Nomor 6 Tahun 2014," in Prosiding Seminar Nasional Pendidikan Akuntansi dan Keuangan, 2015, no. 2, pp. 564-573, [Online]. Available: https://jurnal.fkip.uns.ac.id/index.php/snpak/article/view/6704.

[10] Y. P. Sari, A. Widianto, M. Alfian, R. S. Harjanti, and G. Rahmadiane, "Peningkatan Kapasitas Guru Akuntansi dalam Mata Pelajaran Akuntansi Lembaga (Pelatihan Tata Kelola Keuangan Desa)," J. Abdismas PHB, vol. 3, no. 1, pp. 23-26, 2020, doi: 10.30591/japhb.v3i1.1396.

[11] R. Widuri, Y. Mangoting, E. Tjondro, A. A. Toly, and R. A. Sadjiarto, "Pelatihan Pengelolaan Keuangan dan Sistem Akuntansi Lembaga Pemerintahan Desa Bagi Guru SMK Akuntansi Sidoarjo," J. Serv. Learn., vol. 7, no. 1, pp. 46-51, 2021, doi: 10.9744/share.7.1.46-51.

[12] E. Astuti, J. Murwani, and Sugiharto, "Pelatihan Akuntansi Pemerintahan dan Pengelolaan Dana Desa Pada MGMP Kabupaten Madiun," Din. J. Pengabdi. Kpd. Masy., vol. 4, no. 2, pp. 214-221, 2020, doi: 10.31849/dinamisia.v4i2.3593. 